\title{
Nanogram per Milliliter per Microgram per Meter Squared
}

National Cancer Institute

\section{Source}

National Cancer Institute. Nanogram per Milliliter per Microgram per Meter Squared. NCI

Thesaurus. Code C119451.

A unit of concentration equal to nanograms per milliliter, divided by micrograms per

meter squared. 